\title{
Potential problems and recommendations regarding substitution of generic antiepileptic drugs: a systematic review of literature
}

\author{
Muhammad Atif, Muhammad Azeem and Muhammad Rehan Sarwar
}

\begin{abstract}
Despite the availability of generic antiepileptic drugs (AEDs), still patients and neurologists hesitate to make a switch due to assorted reasons. The objectives of this review were to evaluate the risks associated with the generic substitution of AEDs. In this context, we also summarized the recommendations of various international societies to treat epileptic patients. We used a number of electronic databases to identify the relevant published studies which demonstrated the potential problems and recommendations regarding generic substitution of AEDs. Of 204 articles found initially, 153 were selected for additional review. Subsequently, 68 articles were finally selected. This review concluded that potential problems linked with the generic substitution of AEDs could be bioequivalence issues, failure of drug therapy, emergence of adverse events and increase in the frequency of seizures. The reasons could be the pharmacokinetics properties of AEDs and unique characteristics of some epilepsy patients. Consequently, the generic substitution of AEDs affects the successful treatment and quality of life of the patients. Various guidelines recommend the well-controlled epileptic patients to avoid switching from brand-to-generic products, generic-to-brand products or generic to some other generic products.
\end{abstract}

Keywords: Generic substitution, Pharmacokinetics, Bioequivalence, Bioavailability, Bioinequivalence, Narrow therapeutic index, Antiepileptic drugs

\section{Background}

Epilepsy is a familiar, chronic and critical neurologic disorder characterized by episodes (such as seizures) requiring most of the times a lifelong management (Bialer and Midha 2010; American Medical Association 2009). Being one of the most prevalent diseases, it affects about 50 million people globally and out of them 40 million are from developing countries (World Health Organization 2001). In low-income countries, its incidence may reach at a higher level of 190 in each 100,000 persons (Placencia et al. 1994). Antiepileptic drugs (AEDs) have gained much attention because of the fact that about $70 \%$ of

*Correspondence: rehansarwaralvi@gmail.com

Department of Pharmacy, Faculty of Pharmacy and Alternative Medicine,

The Islamia University of Bahawalpur, Bahawalpur, Punjab, Pakistan the epilepsy patients achieve seizure remission allowing them to live a normal life (Heaney and Sander 2007).

Trepidations about the safety and costs of the medicines have intensified the considerations to the clinical equivalence and role of the generic medicines. These are the products with same active pharmaceutical ingredient(s) (qualitatively as well as quantitatively) as that of the reference product (Van Paesschen et al. 2009). Generic medicines play an important role in patient adherence to the therapy because most of the times these are available at a considerably low price as compared to the branded products (Shrank et al. 2006; Goldman et al. 2007; Kesselheim et al. 2006). Reduction in the healthcare expenditures is crucial for economically compromised patients and those with limited health insurance facilities.

\section{Springer}

(c) 2016 Atif et al. This article is distributed under the terms of the Creative Commons Attribution 4.0 International License (http:// creativecommons.org/licenses/by/4.0/, which permits unrestricted use, distribution, and reproduction in any medium, provided you give appropriate credit to the original author(s) and the source, provide a link to the Creative Commons license, and indicate if changes were made. 
United States' Food and Drug Administration (US FDA) states that, in 1984, about $12 \%$ of the prescriptions included generics and this increased to $44 \%$ in 2000. Regardless of this growth, the increment in the cost accounted for only $8 \%$ (Bialer and Midha 2010).

Nevertheless, the major factor attributed to the extensive use of generic substituents is the reduced cost, yet low cost based generic substitution in epilepsy patients without taking into considerations the unique behavior of the disease is questionable (Jobst and Holmes 2004). Researchers have suggested that during the course of epilepsy treatment, generic substitution should either be avoided or be done with great precautions (Gidal and Tomson 2008; Krämer et al. 2007; Crawford et al. 2006) because it may lead to various complications in the patients. The reasons accountable to these problems are still not fully explored. Consequently, the American Academy of Neurology (AAN), various patient organizations and other medical associations have argued the generic substitution without the physician's approval (Andermann et al. 2007).
The objectives of the current review were to identify potential problems arising from the generic substitution of AEDs with prime focus on their pharmacokinetics parameters, desired outcomes and recommendations.

\section{Review}

\section{Search strategy and selection criteria}

We explored databases (PubMed, ScienceDirect, Google Scholar, Scopus, Medline, Embase, ProQuest, SpringerLink, EconLit, etc.) from 1980 to April 2015 with these keywords: "generic substitution", "pharmacokinetics", "bioequivalence", "bioavailability", "bioinequivalence" and "narrow therapeutic index", together with generic names of antiepileptic drugs in diverse combinations with BOOLEAN and MeSH search. Further publications were recognized by a manual search of the bibliography and reference section of related papers. Of 204 articles found initially, 153 were selected for further review. Of 153 articles, 68 were finally selected (Fig. 1).

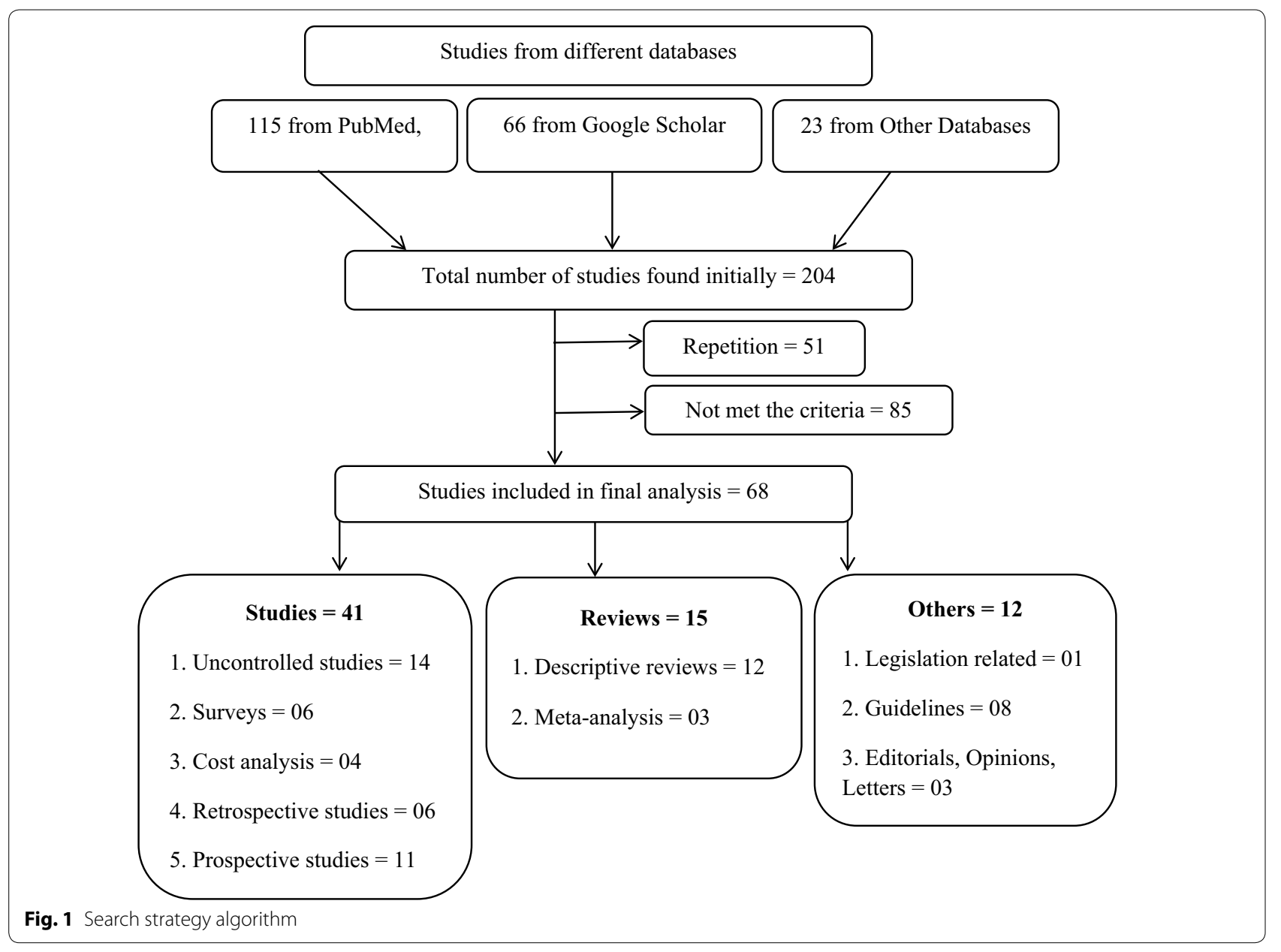




\section{Results and discussion Potential problems with the use of generic antiepileptic drugs}

It is recommended in the several guidelines to monitor the serum levels of AEDs in case generic substitution is made. This is done to confirm that the drug contact stays unaffected (Majkowski et al. 2004; Krämer et al. 2007).

If a dose adjustment is required, it should be done in such a way to avoid potential problems as a consequence of too low (therapy failure) or too high (adverse effects emergence) drug exposure. Preferably, the serum drug levels should be monitored both before and after the generic substitution of AEDs. However, practically it is not possible all the times, and may have cost implications. Furthermore, the serum drug levels of some newer AEDs are inadequately described. Nevertheless, systematically collected data of serum drug concentrations during generic substitution of AEDs offer opportunities to evaluate bioequivalence (BE) in routine care settings, and to identify the generics with potential risks to the patients.
Here, in this review we have summarized some of the problems associated with generic substituted older and newer AEDs among epileptic patients (Table 1).

Although, the reasons of these potential problems are still under-discussion, many researchers have proposed different hypothesis regarding the risks arising due to the generic substitution of AEDs. Three key aspects suggested by many researchers are; pharmacokinetics characteristics of AEDs, wide-ranging bioequivalence criteria and high-risk patient groups.

\section{Pharmacokinetics characteristics of AEDs}

The AEDs have numerous pharmacokinetics factors that may upsurge the probability of problems associated with generic substitution (Table 2) (Crawford et al. 2006; Walker and Patsalos 1995; Perucca 1999; Morselli and Franco-Morselli 1980; Bauer et al. 1982).

Due to these attributes, it is frequently asked whether it is rational to switch the AEDs and pose the patients at the risk of adverse clinical condition. For instance, compromising potential breakthrough seizures and toxicity associated with the generic substitutions of branded

Table 1 Potential problems reported with generic substitution of AEDs

\begin{tabular}{|c|c|c|}
\hline AEDs & Potential problems & References \\
\hline \multirow[t]{4}{*}{ Carbamazepine } & Increased breakthrough seizures with generic substitution & $\begin{array}{l}\text { Sachdeo and Belendiuk (1987), Welty et al. (1992), Koch and Allen } \\
\text { (1987), Hartley et al. (1991), Berg et al. (2008), Hartley et al. (1990) }\end{array}$ \\
\hline & Failure of drug therapy with generic substitution & Meyer et al. (1992), Welty et al. (1992), Jain (1993) \\
\hline & Toxicity and increased serum levels with generic substitution & Gilman et al. (1993), Jumao-as et al. (1989), Reunanen et al. (1992) \\
\hline & Adverse effects with generics & $\begin{array}{l}\text { Neuvonen (1985), Hartley et al. (1990), Olling et al. (1999), Garnett et al. } \\
\text { (2005) }\end{array}$ \\
\hline \multirow[t]{3}{*}{ Phenytoin } & Increased breakthrough seizures with generic substitution & Yamada and Welty (Yamada and Welty 2011), Berg et al. (2008) \\
\hline & Toxicity and increased serum levels with generic substitution & Soryal and Richens (1992) \\
\hline & Adverse effects with generics & Chen et al. (1982) \\
\hline \multirow[t]{4}{*}{ Valproate } & Increased breakthrough seizures with generic substitution & Berg et al. (2008) \\
\hline & Failure of drug therapy & Margolese et al. (2010), Sherr and Kelly (1998) \\
\hline & Toxicity and increased serum levels with generic substitution & Levine et al. (2000) \\
\hline & Adverse effects with generics & $\begin{array}{l}\text { Margolese et al. (2010), Sherwood et al. (1998), Wassef et al. (2005), } \\
\text { Zarate et al. (1999), Schwartz et al. (2000) }\end{array}$ \\
\hline \multirow[t]{2}{*}{ Leviteracetam } & Increased breakthrough seizures with generic substitution & $\begin{array}{l}\text { Armstrong et al. (2010), Fitzgerald and Jacobson (2011), } \\
\text { Chaluvadi et al. (2011) }\end{array}$ \\
\hline & Adverse effects with generics & (Chaluvadi et al. 2011) \\
\hline \multirow[t]{2}{*}{ Topiramate } & Increased breakthrough seizures with generic substitution & Duh et al. (2009b) \\
\hline & Adverse effects with generics & Pineyro-Lopez et al. (2009) \\
\hline Gabapentin & Increased breakthrough seizures with generic substitution & Berg et al. (2008) \\
\hline Phenobarbital & Failure of drug therapy & Bankstahl et al. (2013) \\
\hline Oxcarbazepine & Increased breakthrough seizures with generic substitution & Cook et al. (2009) \\
\hline \multirow[t]{3}{*}{ Lamotrigine } & Increased breakthrough seizures with generic substitution & Makus and McCormick (2007), Nielsen et al. (2008) \\
\hline & Toxicity and increased serum levels with generic substitution & Srichaiya et al. (2008), Sabroe and Sabers (2008), Nielsen et al. (2008) \\
\hline & Adverse effects with generics & Andermann et al. (2007), Makus and McCormick (2007) \\
\hline Primidone & Increased breakthrough seizures with generic substitution & Wyllie et al. (1987) \\
\hline Zonisamide & Increased breakthrough seizures with generic substitution & Berg et al. (2008) \\
\hline
\end{tabular}


Table 2 Pharmacokinetics characteristics of AEDs which may increase the probability of problems associated with their generic substitution

\begin{tabular}{|c|c|c|c|c|}
\hline \multirow[t]{2}{*}{ AEDs } & \multirow[t]{2}{*}{ Therapeutic range } & \multicolumn{3}{|c|}{ Pharmacokinetics parameters } \\
\hline & & Narrow therapeutic range & Low water solubility & Nonlinear pharmacokinetics \\
\hline Carbamazepine & $4-12 \mu \mathrm{g} / \mathrm{ml}$ & Yes & Yes & Yes \\
\hline Phenytoin & $10-20 \mu \mathrm{g} / \mathrm{ml}$ & Yes & Yes & Yes \\
\hline Valproate & $50-100 \mu \mathrm{g} / \mathrm{ml}$ & Yes & No & Yes \\
\hline Phenobarbital & $20-40 \mu \mathrm{g} / \mathrm{ml}$ & Yes & No & No \\
\hline Ethosuximide & $40-100 \mu \mathrm{g} / \mathrm{ml}$ & Yes & No & Yes \\
\hline Gabapentin & $4-20 \mu \mathrm{g} / \mathrm{ml}$ & Yes & No & Yes \\
\hline Lamotrigine & $4-20 \mu \mathrm{g} / \mathrm{ml}$ & No & Yes & No \\
\hline Levetiracetam & $5-40 \mu \mathrm{g} / \mathrm{ml}$ & Yes & No & No \\
\hline Oxcarbazepine & $10-40 \mu \mathrm{g} / \mathrm{ml}$ & Yes & Yes & No \\
\hline Topiramate & $10-20 \mu \mathrm{g} / \mathrm{ml}$ & Yes & Yes & No \\
\hline Tiagibine & $100-300$ ng/ml & Yes & No & No \\
\hline Vigabatrin & $0.8-36 \mu \mathrm{g} / \mathrm{ml}$ & Yes & No & No \\
\hline Primidone & $5-10 \mu \mathrm{g} / \mathrm{ml}$ & Yes & Yes & No \\
\hline Felbamate & $30-100 \mu \mathrm{g} / \mathrm{ml}$ & Yes & Yes & $\mathrm{No}$ \\
\hline Zonisamide & $10-40 \mu \mathrm{g} / \mathrm{ml}$ & Yes & Yes & Yes \\
\hline
\end{tabular}

carbamazepine and phenytoin respectively (Gidal and Tomson 2008).

According to the FDA, a drug is categorized as NTI if the minute changes in dose or blood concentration might cause dose and blood concentration dependent severe therapeutic failures or adverse drug reactions (Yu 2011). NTI indicates that small differences in the absorption of drugs may cause or lead to substantial negative impacts on health. NTI of AEDs compels the healthcare professionals to continuously monitor the plasma levels of these drugs.

According to the prescribers, there are certain drugs that pose problems upon generic substitution, such drugs can be described as NTI (Nuwer et al. 1990). In general, the therapeutic dose of almost all AEDs vary across patients. Therefore, it is highly recommended to individualize the dose of AEDs based on the dose-response data of that particular patient (Crawford et al. 2006). This is applicable to almost all AEDs even wider therapeutic index and low toxicity profile drugs such as lamotrigine (Guberman and Corman 2000).

\section{Wide ranging bioequivalence criteria}

The best method to ensure therapeutic equivalency of pharmaceutical products is bioequivalence (BE). The bioequivalency of the generic products have been approved by the FDA since the enforcement of the Drug Price Competition and Patent term Restoration Act in 1984 (Hatch-Waxman Amendments) (Karki 2005). According to the FDA, when two drugs are bioequivalent, it means that both of them will provide similar and desired clinical effects. Bioequivalence can be determined by maximum concentration of a drug in the plasma $\left(\mathrm{C}_{\max }\right)$ and the area under the plasma level-time curve up to the last quantifiable concentration (AUCt) (Nightingale and Morrison 1987; Henney 1999; Bialer and Midha 2010).

The criteria set by majority of the regulatory authorities for two products to be bioequivalent is that the AUC and $\mathrm{C}_{\max }$ ratios of both the products should fall within a range of $80-125 \%$ with $90 \%$ confidence intervals (CI) (Chenu et al. 2009; FDA 2003). It would be beneficial to clearly specify the size of the CI for BE studies. As for practical purposes, generics of branded drugs have AUC and $\mathrm{Cmax}$ ratios that are very close to 1 . With significant differences in either value, it would be unlikely for the CI to lie within the range of 80-125\% (Midha and McKay 2009).

As far as two different generics of the same brand are concerned, there could be differences in their $\mathrm{C}_{\max }$ and AUC values. Such type of deviations are very significant for the medicinal products which have NTI, poor solubility, excitatory or inhibitory effects on hepatic enzymes and/or those with non-linear pharmacokinetics (e.g. anticonvulsants) (Crawford et al. 2006; Borgheini 2003). Recently, two articles (using Monte Carlo methods) focused on the quantitative assessment of the generic AEDs, and used classic (80-125 \%) and tighter (90$111.11 \%)$ BE limits. It was verified that generic AEDs should not be considered as therapeutically equivalent products (Karalis et al. 2013, 2014). 
The approval of NTI generic products based on the $\mathrm{BE}$ parameters is highly controversial because apparently there could be slight differences in the values but the effects could be diverse (Meredith 2003; Browne and Holmes 2001). Another important consideration in the context of generic substitution is the frequent change in the supply source of generic medicines which may compromise the condition of the patient (Meredith 2003). Change in the supply source of medicines is mainly due to availability of generic products at a lower cost. However, the complications arising from generic substitution of some medicines, for example AEDs, direct the physicians and pharmacists to select the medicines based on brand names, specifically in high risk patient groups (Table 3). The published studies have already reported that many prescribers and physicians avoided and opposed the generic substitution of the AEDs because of a greater risk of breakthrough seizures (Perucca et al. 2006; Jobst and Holmes 2004).

\section{High-risk patient groups}

The problems caused by generic substitution of AEDs may particularly be significant in some specific groups of patients (Table 3). There are no systematic studies available regarding these high-risk groups, and there is little or no availability of any documented evidence that allow the quantification of the actual effect of these problems. However, physicians and pharmacists should remain alert to the problems and risks while substituting the generics. Patient-related information on their previous experiences of the generic substitution could also be beneficial to identify the risk-to-benefit ratio of generic substitution.

Examples of proposed risks to epileptic patients associated with generic substitution of medicines include; limited availability of dosage forms, drug elimination problems in renal or hepatic compromised patients, etc. AEDs have pharmacokinetics interactions with oral contraceptives so these may cause problems when used concomitantly (Crawford 2002). Generic substitution of AEDs may cause an abrupt change in the plasma concentration of the drugs, and consequently there might be failure of contraceptive therapy (Tettenborn 2006).

\section{Recommendations from the international societies}

We have summarized the recommendations of various neurological societies in Table 4.

\section{Limitations}

Few AEDs for example, divalproex sodium and topiramate are also used as prophylactic agents for migraine (Chiossi et al. 2014; Steiner et al. 2007; Steiner 2005). But, due to the limited data available on the generic substitution of AEDs in migraine patients, and no such recommendations from the headache organizations (American Academy of Neurology and American Headache Society), we mainly focused on the potential problems and recommendations regarding generic substitution of AEDs in epilepsy patients.

\section{Conclusion and recommendations}

Generic substitution is preferred to reduce the healthcare costs. However, the available literature on epilepsy indicate that substitution of AEDs is problematic, especially in certain patient groups. Generic-to-generic substitution is even not recommended based on the unavailability of BE data. Similarly, the wide-ranging criteria for bioequivalence permit variations in the drug exposure that might be clinically significant and require plasma level monitoring to avoid failure of drug therapy or incidence of adverse effects. Due to the potential risk of losing the control over seizures, various guidelines recommend that the well-controlled epileptic patients should avoid switching from brand-to-generic products, generic-tobrand products and generic-to-generic products.

As few AEDs are also used for the prophylaxis of migraine we recommend that the researchers and the

Table 3 Special categories of patients recommended for exclusion from the compulsory generic substitution (Lamy 1986; Krämer et al. 2007; Crawford et al. 2006)

\begin{tabular}{ll}
\hline Special categories & Examples \\
\hline High risk patients & $\begin{array}{l}\text { Extreme age groups, pregnant women, patients with multiple disorders being treated with several drugs, solitary individual, etc. } \\
\text { High risk diseases }\end{array}$ \\
$\begin{array}{l}\text { Chronic diseases, diseases aggravated after the administration of drugs prescribed for co-morbid condition, etc. } \\
\text { Narrow therapeutic index drugs, drugs requiring individualization of dose, drugs exhibiting severe drug-drug interactions, drugs } \\
\text { with the complex therapeutic regimen, drugs initiating the prescribing cascade, etc. }\end{array}$ \\
\hline
\end{tabular}


Table 4 Guidelines for generic prescription of AEDs (Krämer et al. 2007; Connock et al. 2006; Perucca et al. 2006; Network 2003; Liow et al. 2007; American Academy of Neurology 1990; Duh et al. 2009a; Bialer and Midha 2010)

\begin{tabular}{|c|c|c|}
\hline Country & Organization & Principal recommendations \\
\hline \multirow[t]{4}{*}{ United States } & AAN & $\begin{array}{l}\text { The AAN argues the generic substitution of AEDs and advises to seek consent of attending } \\
\text { physician }\end{array}$ \\
\hline & Epilepsy Foundation & $\begin{array}{l}\text { Both physician and patient should give consent and to be notified upon substitution of } \\
\text { AEDs }\end{array}$ \\
\hline & FDA & $\begin{array}{l}\text { According to the FDA, a therapeutically equivalent product (either generic or brand) may } \\
\text { be expected to have equivalent clinical effects }\end{array}$ \\
\hline & American Epilepsy Society & $\begin{array}{l}\text { The physicians involved in epilepsy treatment are trained for selection of appropriate AEDs } \\
\text { and their dosages to minimize or eradicate seizures and to avoid adverse events } \\
\text { It is done by utilizing the best available scientific evidences and clinical expertise } \\
\text { Also, the society contradicts the formulation substitution of AEDs without obtaining } \\
\text { approval from the physician as well as the patient }\end{array}$ \\
\hline England & NICE & $\begin{array}{l}\text { Be precautious while generic substitution of AEDs having complex pharmacokinetics that } \\
\text { may cause larger differences in therapeutic effects upon minor changes in drug absorp- } \\
\text { tion }\end{array}$ \\
\hline Germany & German chapter of ILAE & $\begin{array}{l}\text { A switch must be avoided for patients having well-controlled seizures } \\
\text { Consider a generic switch towards a lower cost AED only for the patients having poorly } \\
\text { controlled seizures. It is better to initiate the treatment with a low-cost AED } \\
\text { The serum drug levels should be monitored closely while switching and the patient } \\
\text { should be informed about the potential risks }\end{array}$ \\
\hline Italy & Italian chapter of ILAE & $\begin{array}{l}\text { For patients exhibiting partial controlled seizures upon treatment with a brand AED, it } \\
\text { might be appropriate to switch to a generic product } \\
\text { The patient should be informed about the properties and nature of these products } \\
\text { A switch is not recommended for the patients having well-controlled seizures }\end{array}$ \\
\hline France & LFCE & $\begin{array}{l}\text { AEDs belong to a class that may cause problems when substituted. It is recommended to } \\
\text { avoid generic substitution of AEDs }\end{array}$ \\
\hline Poland & Polish Society of Epileptology & $\begin{array}{l}\text { Because of an increased risk of deterioration in epilepsy patients switching of formulations } \\
\text { is contraindicated } \\
\text { Pharmacists should not make substitution without informing the physicians and the physi- } \\
\text { cians are responsible to make aware the patients of all the potential and possible risks }\end{array}$ \\
\hline Scotland & Scottish Intercollegiate Guidelines Network & $\begin{array}{l}\text { Generic substitution of AEDs should not be made as different available formulations of } \\
\text { AEDs are not switchable }\end{array}$ \\
\hline Sweden & Swedish Medicinal Products Agency & Switching between formulations may cause a poor control of seizures \\
\hline Netherland & Netherlands Society of Child Neurology & The substitution of AEDs is not recommended \\
\hline
\end{tabular}

AAN American Academy of Neurology, FDA Food and Drug Administration, NICE National Institute for Health and Care Excellence, ILAE International League Against Epilepsy, LFCE Ligue Francaise Contre L'Epilepsie

associated organizations should conduct similar studies in migraine patients to evaluate the potential benefits and problems with generic substitution, and based on the results recommendations could be made for such patients.

\section{Abbreviations}

AAN: American Academy of Neurology; AEDs: antiepileptic drugs; AUC: area under the plasma level-time curve; BE: bioequivalence; ILAE: International League Against Epilepsy; LFCE: Ligue Francaise Contre L'Epilepsie; NICE: National Institute for Health and Care Excellence; NTI: narrow therapeutic index; US FDA: United States' Food and Drug Administration.

\section{Authors' contributions}

MRS, MAZ and MAT contributed in the concept and design of this review article. MAZ and MRS did the literature search. MAT critically revised the paper for important intellectual content. All authors read and approved the final manuscript.

\section{Competing interests}

The authors declare that they have no competing interests.

\section{Funding}

No funding was involved in the preparation of this article or in the decision to submit it for publication.

Received: 18 September 2015 Accepted: 15 February 2016

Published online: 25 February 2016

\section{References}

American Academy of Neurology (1990) Assessment: generic substitution for antiepileptic medication. Neurology 40:1641-1643

American Medical Association (2009) Featured Report; Generic Drugs (A-02). In: June 2002 AMA Annual Meeting

Andermann F, Duh MS, Gosselin A, Paradis PE (2007) Compulsory generic switching of antiepileptic drugs: high switchback rates to branded compounds compared with other drug classes. Epilepsia 48(3):464-469. doi:10.1111/j.1528-1167.2007.01007.x

Armstrong TS, Choi S, Walker J, Gilbert MR (2010) Seizure risk in brain tumor patients with conversion to generic levetiracetam. J Neurooncol 98(1):137-141. doi:10.1007/s11060-009-0066-3

Bankstahl M, Bankstahl JP, Löscher W (2013) Is switching from brand name to generic formulations of phenobarbital associated with loss of 
antiepileptic efficacy? A pharmacokinetic study with two oral formulations (Luminal ${ }^{\circledR}$ vet, Phenolepti ${ }^{\circledR}$ ) in dogs. BMC Vet Res 9(1):202

Bauer LA, Harris C, Wilensky AJ, Raisys VA, Levy RH (1982) Ethosuximide kinetics: possible interaction with valproic acid. Clin Pharmacol Ther 31(6):741-745

Berg MJ, Gross RA, Tomaszewski KJ, Zingaro WM, Haskins LS (2008) Generic substitution in the treatment of epilepsy: case evidence of breakthrough seizures. Neurology 71(7):525-530. doi:10.1212/01. wnl.0000319958.37502.8e

Bialer M, Midha KK (2010) Generic products of antiepileptic drugs: a perspective on bioequivalence and interchangeability. Epilepsia 51(6):941-950. doi:10.1111/j.1528-1167.2010.02573.x

Borgheini G (2003) The bioequivalence and therapeutic efficacy of generic versus brand-name psychoative drugs. Clin Ther 25(6):1578-1592

Browne TR, Holmes GL (2001) Epilepsy. N Engl J Med 344(15):1145-1151. doi:10.1056/NEJM200104123441507

Chaluvadi S, Chiang S, Tran L, Goldsmith CE, Friedman DE (2011) Clinical experience with generic levetiracetam in people with epilepsy. Epilepsia 52(4):810-815. doi:10.1111/j.1528-1167.2011.03025.x

Chen SS, Allen J, Oxley J, Richens A (1982) Comparative bioavailability of phenytoin from generic formulations in the United Kingdom. Epilepsia 23(2):149-152

Chenu F, Batten LA, Zernig G, Ladstaetter E, Hebert C, Blier P (2009) Comparison of pharmacokinetic profiles of brand-name and generic formulations of citalopram and venlafaxine: a crossover study. J Clin Psychiatry 70(7):958-966

Chiossi L, Negro A, Capi M, Lionetto L, Martelletti P (2014) Sodium channel antagonists for the treatment of migraine. Expert Opin Pharmacother 15(12):1697-1706

Cook A, Bensalem-Owen M, Owens-Acey T, McKee H, Sinclair K, Fakhoury T (2009) Pharmacokinetic variations and impact on seizures after brand to generic substitution of oxcarbazepine in adults with epilepsy. In: Epilepsia. Wiley-Blackwell Publishing, Inc Commerce Place, 350 Main St, Malden, 02148, MA, USA, pp 111-111

Crawford P (2002) Interactions between antiepileptic drugs and hormonal contraception. CNS Drugs 16(4):263-272

Crawford P, Feely M, Guberman A, Kramer G (2006) Are there potential problems with generic substitution of antiepileptic drugs?: a review of issues. Seizure 15(3):165-176

Connock M, Frew E, Evans BW, Bryan S, Cummins C, Fry-Smith A, Li Wan Po A, Sandercock J (2006) The clinical effectiveness and cost-effectiveness of newer drugs for children with epilepsy. A systematic review. Health Technol Assess 10(7). doi:10.3310/hta10070

Duh MS, Cahill KE, Paradis PE, Cremieux PY, Greenberg PE (2009a) The economic implications of generic substitution of antiepileptic drugs: a review of recent evidence. Expert Opin Pharmacother 10(14):2317-2328. doi:10.1517/14656560903140525

Duh MS, Paradis PE, Latremouille-Viau D, Greenberg PE, Lee SP, Durkin MB, Wan GJ, Rupnow MF, LeLorier J (2009b) The risks and costs of multiple-generic substitution of topiramate. Neurology 72(24):2122-2129. doi:10.1212/ WNL.0b013e3181aa5300

FDA (2003) Guidance for industry: bioavailability and bioequivalence studies for orally administered drug products—general considerations. Food and Drug Administration, Washington, DC

Fitzgerald CL, Jacobson MP (2011) Generic substitution of levetiracetam resulting in increased incidence of breakthrough seizures. Ann Pharmacother 45(5):e27. doi:10.1345/aph.1P765

Garnett WR, Gilbert TD, O'Connor P (2005) Patterns of care, outcomes, and direct health plan costs of antiepileptic therapy: a pharmacoeconomic analysis of the available carbamazepine formulations. Clin Ther 27(7):1092-1103. doi:10.1016/j.clinthera.2005.07.008

Gidal BE, Tomson T (2008) Debate: substitution of generic drugs in epilepsy: is there cause for concern? Epilepsia 49(s9):56-62

Gilman JT, Alvarez LA, Duchowny M (1993) Carbamazepine toxicity resulting from generic substitution. Neurology 43(12):2696-2697

Goldman DP, Joyce GF, Zheng Y (2007) Prescription drug cost sharing: associations with medication and medical utilization and spending and health. JAMA 298(1):61-69. doi:10.1001/jama.298.1.61

Guberman A, Corman C (2000) Generic substitution for brand name antiepileptic drugs: a survey. Can J Neurol Sci 27(1):37-43
Hartley R, Aleksandrowicz J, Bowmer CJ, Cawood A, Forsythe WI (1991) Dissolution and relative bioavailability of two carbamazepine preparations for children with epilepsy. J Pharm Pharmacol 43(2):117-119

Hartley R, Aleksandrowicz J, Ng PC, McLain B, Bowmer CJ, Forsythe WI (1990) Breakthrough seizures with generic carbamazepine: a consequence of poorer bioavailability? Br J Clin Pract 44(7):270-273

Heaney DC, Sander JW (2007) Antiepileptic drugs: generic versus branded treatments. Lancet Neurol 6(5):465-468. doi:10.1016/ S1474-4422(07)70105-9

Henney JE (1999) Review of generic bioequivalence studies. JAMA 282(21):1995

Jain K (1993) Investigation and management of loss of efficacy of an antiepileptic medication using carbamazepine as an example. J R Soc Med 86(3):133-136

Jobst BC, Holmes GL (2004) Prescribing antiepileptic drugs: should patients be switched on the basis of cost? CNS Drugs 18(10):617-628

Jumao-as A, Bella I, Craig B, Lowe J, Dasheiff RM (1989) Comparison of steady-state blood levels of two carbamazepine formulations. Epilepsia 30(1):67-70

Karalis V, Bialer M, Macheras P (2013) Quantitative assessment of the switchability of generic products. Eur J Pharm Sci 50(3-4):476-483. doi:10.1016/j. ejps.2013.08.023

Karalis V, Macheras P, Bialer M (2014) Generic products of antiepileptic drugs: a perspective on bioequivalence, bioavailability, and formulation switches using Monte Carlo simulations. CNS drugs 28(1):69-77

Karki L (2005) Review of FDA law related to pharmaceuticals: the Hatch-Waxman Act, regulatory amendments and implications for drug patent enforcement. J Pat Trademark Off Soc'y 87:602

Kesselheim AS, Fischer MA, Avorn J (2006) Extensions of intellectual property rights and delayed adoption of generic drugs: effects on medicaid spending. Health Aff (Millwood) 25(6):1637-1647. doi:10.1377/ hlthaff.25.6.1637

Koch G, Allen JP (1987) Untoward effects of generic carbamazepine therapy. Arch Neurol 44(6):578-579

Krämer G, Biraben A, Carreno M, Guekht A, De Haan G, Jędrzejczak J, Josephs D, Van Rijckevorsel K, Zaccara G (2007) Current approaches to the use of generic antiepileptic drugs. Epilepsy Behav 11(1):46-52

Lamy PP (1986) Generic equivalents: issues and concerns. J Clin Pharmacol 26(5):309-316

Levine J, Chengappa KN, Parepally H (2000) Side effect profile of entericcoated divalproex sodium versus valproic acid. J Clin Psychiatry 61(9):680-681

Liow K, Barkley GL, Pollard JR, Harden CL, Bazil CW, American Academy of Neurology (2007) Position statement on the coverage of anticonvulsant drugs for the treatment of epilepsy. Neurology 68(16):1249-1250. doi:10.1212/01. wnl.0000259400.30539.cc

Majkowski J, Lason W, Daniel W (2004) Brand-name and generic drugs in the treatment of epilepsy: biopharmaceutical, pharmacological, clinical and economic problems. Epileptologia 12:365-389

Makus KG, McCormick J (2007) Identification of adverse reactions that can occur on substitution of generic for branded lamotrigine in patients with epilepsy. Clin Ther 29(2):334-341

Margolese HC, Wolf Y, Desmarais JE, Beauclair L (2010) Loss of response after switching from brand name to generic formulations: three cases and a discussion of key clinical considerations when switching. Int Clin Psychopharmacol 25(3):180-182

Meredith P (2003) Bioequivalence and other unresolved issues in generic drug substitution. Clin Ther 25(11):2875-2890

Meyer MC, Straughn AB, Jarvi EJ, Wood GC, Pelsor FR, Shah VP (1992) The bioinequivalence of carbamazepine tablets with a history of clinical failures. Pharm Res 9(12):1612-1616

Midha KK, McKay G (2009) Bioequivalence; its history, practice, and future. AAPS J 11(4):664-670. doi:10.1208/s12248-009-9142-z

Morselli PL, Franco-Morselli R (1980) Clinical pharmacokinetics of antiepileptic drugs in adults. Pharmacol Ther 10(1):65-101

Network SIG (2003) Diagnosis and management of epilepsy in adults. A national clinical guideline. Guideline No. 70. Edinburgh. SIGN

Neuvonen PJ (1985) Bioavailability and central side effects of different carbamazepine tablets. Int J Clin Pharmacol Ther Toxicol 23(4):226-232 
Nielsen KA, Dahl M, Tommerup E, Wolf P (2008) Comparative daily profiles with different preparations of lamotrigine: a pilot investigation. Epilepsy Behav 13(1):127-130. doi:10.1016/j.yebeh.2008.02.020

Nightingale SL, Morrison JC (1987) Generic drugs and the prescribing physician. JAMA 258(9):1200-1204

Nuwer MR, Browne TR, Dodson WE, Dreifuss FE, Engel J Jr, Leppik IE, Mattson RH, Penry J, Treiman DM, Wilder BJ (1990) Generic substitutions for antiepileptic drugs. Neurology 40(11):1647-1651

Olling M, Mensinga TT, Barends DM, Groen C, Lake OA, Meulenbelt J (1999) Bioavailability of carbamazepine from four different products and the occurrence of side effects. Biopharm Drug Dispos 20(1):19-28

Perucca E (1999) The clinical pharmacokinetics of the new antiepileptic drugs. Epilepsia 40(Suppl 9):S7-13

Perucca E, Albani F, Capovilla G, Bernardina BD, Michelucci R, Zaccara G (2006) Recommendations of the Italian League against Epilepsy working group on generic products of antiepileptic drugs. Epilepsia 47(Suppl 5):16-20. doi:10.1111/j.1528-1167.2006.00871.x

Pineyro-Lopez A, Pineyro-Garza E, Gomez-Silva M, Reyes-Araiza R, Flores-Diego MA, Borrego-Alvarado S, Gamino-Pena ME, Vargas-Zapata R, Salazar-Leal ME (2009) Bioequivalence of single 100-mg doses of two oral formulations of topiramate: an open-label, randomized-sequence, two-period crossover study in healthy adult male Mexican volunteers. Clin Ther 31(2):411-417. doi:10.1016/j.clinthera.2009.02.001

Placencia M, Sander JW, Roman M, Madera A, Crespo F, Cascante S, Shorvon SD (1994) The characteristics of epilepsy in a largely untreated population in rural Ecuador. J Neurol Neurosurg Psychiatry 57(3):320-325

Reunanen M, Heinonen EH, Nyman L, Anttila M (1992) Comparative bioavailability of carbamazepine from two slow-release preparations. Epilepsy Res 11(1):61-66

Sabroe TP, Sabers A (2008) Progressive anticonvulsant hypersensitivity syndrome associated with change of drug product. Acta Neurol Scand 117(6):428-431. doi:10.1111/j.1600-0404.2007.00976.x

Sachdeo RC, Belendiuk G (1987) Generic versus branded carbamazepine. Lancet 1(8547):1432

Schwartz TL, Massa JL, Gupta S, Al-Samarrai S, Devitt P, Masand PS (2000) Divalproex sodium versus valproic acid in hospital treatment of psychotic disorders. Prim Care Companion J Clin Psychiatry 2(2):45-48

Sherr JD, Kelly DL (1998) Substitution of immediate-release valproic acid for divalproex sodium for adult psychiatric inpatients. Psychiatr Serv 49(10):1355-1357. doi:10.1176/ps.49.10.1355

Sherwood BE, Shellhorn E, Suppes T (1998) Gastrointestinal side-effects after switch to generic valproic acid. Pharmacopsychiatry 31(3):114

Shrank WH, Hoang T, Ettner SL, Glassman PA, Nair K, DeLapp D, Dirstine J, Avorn J, Asch SM (2006) The implications of choice: prescribing generic or preferred pharmaceuticals improves medication adherence for chronic conditions. Arch Intern Med 166(3):332-337. doi:10.1001/ archinte.166.3.332
Soryal I, Richens A (1992) Bioavailability and dissolution of proprietary and generic formulations of phenytoin. J Neurol Neurosurg Psychiatry 55(8):688-691

Srichaiya A, Longchoopol C, Oo-Puthinan S, Sayasathid J, Sripalakit P, Viyoch J (2008) Bioequivalence of generic lamotrigine 100-mg tablets in healthy Thai male volunteers: a randomized, single-dose, two-period, twosequence crossover study. Clin Ther 30(10):1844-1851. doi:10.1016/j. clinthera.2008.10.018

Steiner TJ (2005) Lifting The Burden: the global campaign to reduce the burden of headache worldwide. J Headache Pain 6(5):373-377

Steiner TJ, Paemeleire K, Jensen R, Valade D, Savi L, Lainez MJ, Diener HC, Martelletti P, Couturier EG, European Headache Federation, Lifting The Burden: The Global Campaign to Reduce the Burden of Headache Worldwide, World Health Organization (2007) European principles of management of common headache disorders in primary care. J Headache Pain Suppl 1:S3-S47

Tettenborn B (2006) Management of epilepsy in women of childbearing age: practical recommendations. CNS Drugs 20(5):373-387

Van Paesschen W, Hauman H, Lagae L (2009) The use of generic medication in epilepsy: a review of potential issues and challenges. Eur J Paediatr Neurol 13(2):87-92

Walker MC, Patsalos PN (1995) Clinical pharmacokinetics of new antiepileptic drugs. Pharmacol Ther 67(3):351-384

Wassef AA, Winkler DE, Roache AL, Abobo VB, Lopez LM, Averill JP, Mian Al, Overall JE (2005) Lower effectiveness of divalproex versus valproic acid in a prospective, quasi-experimental clinical trial involving 9,260 psychiatric admissions. Am J Psychiatry 162(2):330-339

Welty TE, Pickering PR, Hale BC, Arazi R (1992) Loss of seizure control associated with generic substitution of carbamazepine. Ann Pharmacother 26(6):775-777

World Health Organization (2001) The Global Campaign against Epilepsy. Information Pack for the Launch of the Global Campaign's Second Phase, Geneva, 12-13

Wyllie E, Pippenger CE, Rothner AD (1987) Increased seizure frequency with generic primidone. JAMA 258(9):1216-1217

Yamada M, Welty TE (2011) Generic substitution of antiepileptic drugs: a systematic review of prospective and retrospective studies. Ann Pharmacother 45(11):1406-1415. doi:10.1345/aph.1Q349

Yu L (2011) Quality and bioequivalence standards for narrow therapeutic index drugs. http://www.fda.gov/downloads/Drugs/DevelopmentApprovalProcess/HowDrugsareDevelopedandApproved/ApprovalApplications/AbbreviatedNewDrugApplicationANDAGenerics/UCM292676.pdf. Accessed 18 Jan 2016

Zarate CA Jr, Tohen M, Narendran R, Tomassini EC, McDonald J, Sederer M, Madrid AR (1999) The adverse effect profile and efficacy of divalproex sodium compared with valproic acid: a pharmacoepidemiology study. J Clin Psychiatry 60(4):232-236

\section{Submit your manuscript to a SpringerOpen ${ }^{\circ}$ journal and benefit from:}

- Convenient online submission

- Rigorous peer review

- Immediate publication on acceptance

- Open access: articles freely available online

- High visibility within the field

- Retaining the copyright to your article

Submit your next manuscript at springeropen.com 